\title{
THE THEME OF ALIENATION IN THE SELECT NOVELS OF ANITA DESAI
}

M.Kalyankumar

Lecturer in English

SKIT, Srikalahasti
Anita Desai is the prestigious representative of Indian English Fiction. Her novels reveal the extreme complexities of human life. The theme of Alienation is very striking in the novels of Anita Desai. The novelist touches the inner and outer worlds of individuals and their relationships in the family is very interesting to know. The present paper is about the theme of Alienation in the novels of Anita Desai. How the writer touches the inner and outer worlds of the individual feelings and their relationships in the family.

The term alienation refers to strange, other etc. alienation is estrangement from other characters, society or work, a blocking or different from other person's feelings. The alienation of individual is in alienable. Once cannot been the world, if alienation present in one's soul. Alienation being the root cause of psychological problems. Anita Desai brings into focus the part played by the unconscious and the brokered self in the transformation of the subject under unbearable societal pressures, her male and female characters struggle with their alienated selves and sufferings.

A mentally deficient person experiences alienation; similarly persons of superior talents and competencies suffer imposed alienation and alienation of superior intellect at the hands of lesscapable, minimal knowledge, nonunderstanding persons and the unsympathetic and hostile society around. The persona becomes self estranged because the person enjoys nothing for his own sake. Men like Nirode in Voices in the City, Dev in Bye-Bye Black Bird and Baba in Clear Light of the Day, Suffer from self -imposed alienation, artistic alienation of the race and alienation of the competitive society. They are the victims of neurosis, unreason and loneliness.

However Anita Desai is a successful novelist in literary world. She lies and eternal impact on her readers with her psychological novels. Her imagination and lyrical fragrance are highly appreciable. According to Anita Desai it 


\section{ELK}

\section{Asia Pacific Journals}

has been her personal luck that her temperament and circumstance

Stair cause that leads up, up, up, they ascend to philosophy, then poetry, and from there to music someone will go and fetch a harmonium and the singing beings. None of your classical that, but out Our own southern religious bhajans On end on, half through the night.(p.66)

This difference in the attitude of it towards his father stands in sharp contrast with that of Nirode while it serves as a foil to the embittered attitude of Nirode, it also suggests very powerfully that all is not lost in regard to human relationships. And it been so, we would have found ourselves living in a world of unrelieved gloom and unmitigated despair.

Monisha also like her brother becomes a miserable person and the part that parental influences must have played in this respect can be easily understood, but there is no clear mention of this fact in the novel. Monisha is married to Jiben but their married life is devoid of happiness and satisfaction. There are temper mental differences between them. Monisha is a lady with an intellectual bent of mind but
ELK Asia Pacific Journals - Special Issue ISBN: 978-81-930411-1-6

jiben is a practical down to earth man and is essentially mediocre. It is the joint family which proves to be an obstacle in their happiness. She has to suffer the slings and arrows of the taunts and tortures of the joint family.

It is quite natural for Monisha to adopt a strategy of an escape into the past as a result of which she recalls her stay with ban at the last place of posting out in a district, away from the city and the family. "The solitude of the jungles there, the aqueous showdowns of the bamboo groves and the earth lay with great fallen leaves. The bell-like dignity, of the elephant on which we rode through the jungles jiben away on tour alone with me, no visitors at all."

Monisha is acutely aware of all these elements which alienate her from her husband's family and her own words from her diary bring out her miserable condition which is the outcome of an unhappy married life. Monisha is a significant character in the novel voices in the city, an in her life the novelist has presented alienation of marital discord. In this novel she is married to jiben and is a daughterin-law of a joint family. Her incapacity to bear a child is subject or ridicule amongst the elderly female members of the family. 
ELK

Asia Pacific Journals

She is shocked to find that her under clothes and Saris there examines by these elderly ladies in the most vulgar manner.

What hurts Monisha very deeply is that her capacity to bear a child is not viewed with the least sympathy with the least sympathy, and she is frequently subjected to the bantering remarks by the elderly ladies of the family Monisha is not only a highly educated woman, but she has intellectual accomplishments of a high order. She has a library of her own which consists of the classics of different languages. The tragedy of her life is that she gets no leisure and privacy to go through these books and feel delighted. She is deeply pained to observe that her love for books is also laughs are and she makes a pointed reference to the remarks of Kalyani on Monisha is in the form of a diary and this particularly painful aspect of her life has been described in these words:

The whole wardrobe full of books. To my perplexity, she laughs. She says, "I got a hundred and eleven", and I am no longer per flexed: I see that there is nothing to laugh at in Katka or Hopkins or Dostoevsky or my Russian or French or
ELK Asia Pacific Journals - Special Issue ISBN: 978-81-930411-1-6

Sanskrit dictionaries. But I wish they would leave me alone, sometimes, to read. Or that Nirode would come again and take me away tom sit under a tree with him. He has not come.

Monisha's tragic death arouses philosophic thoughts in Nirode. What is surprising is that this moment he does not suffer from a sense of depression. Voices in the City is unquestionably a powerful novel of Anita Desai. It is remarkable for lively presentation of alienation and emotional world of chief protagonists Nirode and Monisha, Calcutta is an invisible protagonist in this novel. Nirode suffers from self-imposed alienation of the competitive city. However of the end of the novel, Nirode collects courage to confront life on its own twems with a view to remaking and redefining his life. $\mathrm{He}$ moves from a stage of self alienation to self identify, and Monisha is moves from the state of alienation of loneliness in joint family.

Most of her characters hail from the well to do sections of Indian society. They often run away from their homes to some hill station, some ancestral mansion, from village to city or vice versa. In B. 
Ramachandra Rao's view the problem with them is not poverty, hunger or starvation; they suffer from psychologically complicated situations, "they passionately discuss issues like conformity and rebellion, attachment and detachment" (33). The ethical messages of the Bhagwad Gita have underpinnings in her novels like Cry the Peacock and Voices in the City.

The locales presented by Anita Desai exert their influence on the characters affecting their attitudes. The beauty of the gardens of Rai Sahib in Cry the Peacock, the deserted look of Manori in Where Shall We Go This Summer, the emptiness of Carignano in Fire on the Mountain, the attractive aspects of the city of London and the compelling force of the countryside in Bye Bye Blackbird are all a part of the novelist's plan and the locales correspond to the psychological states of the characters

Anita Desai's novels have been structurally composed in the framework of death and destruction from which there is no protection and she, having an existential leaning, makes her theme maladjustment and absurdity of human existence and accordingly her characters, in their attempts to fulfill the higher needs of the individual inner nature, are not able to keep their married life happy.

Barring a couple of her novels like Voices in the City, In Custody, Baumgartner's Bombay and to certain extent Bye Bye Blackbird, in most of the novels of Anita Desai female characters are the protagonists but the presence of men remains very much in the minds and lives of their women relations. Even the absence of these male characters, like fathers of Maya and Sita, husbands of Sarah and Nanda Kaul can be noticed to be quite conspicuous. Sarah is never able to shed the thought of Adit from her mind and Raka cannot forget her father's attitude to her mother.

The alienation of Sarah from the English society in Bye Bye Blackbird is the consequence of her fear, her intense desire to escape from the curiosity and personal questions of the English. The image of her walk along the pavements hiding something reflects Sarah's wish to conceal the fact that she is the wife of an Indian; She darted along the pavements as if on sliding skates, widely skirting the parked milk van, hurrying her steps at the sound of approaching foot falls as though she were fleeing, holding this thing, this weakness inside her coat, hidden from 
them, from their curiosity, their questions, their touch.(30) The verbal expressions used here are the embodiment of her alienation out of the fear.

Anita Desai has displayed different psychic symbolical devices and telling images. The symbols used by her do not seem to have been used on purpose, they are actually a part of the circumstantial details of the narrative and they gather significance because they have a close correlation with the events and happenings. The dust storm in Cry the Peacock is highly suggestive. It externalizes Maya's, perceptions, the idea of murder might have come to the surface of her consciousness and the vibrations and the harsh sounds of the blowing wind find echo in the tormented rhythms of Maya's mind.

In order to enhance the required effect Anita Desai has sometimes employed images suggesting togetherness in contrast to alienation as in Cry the Peacock, a dark young man and a dark young woman smiling at each other (94), and in Where Shall We Go This Summer the image of Muslim woman and a man lost in love in the Hanging Garden (146) serve to render the alienation of the characters in a stranger way. Even Sita's withdrawal to Manori is significant as she badly needs love. The memory of that Muslim couple does not relate to her personal life. It is the dearth of love in her life which torments her. When she learns about Raman's visit to the island supposedly his second visit to fetch Sita, in spite of her wish to "lay down her head and weep"(131), she is left with a sense of having been betrayed by everyone.)

Where the desired atmosphere in Cry The Peacock is effectively evoked by the prophecy of the albino astrologer and the letter of Arjuna, the derelict houses in Where Shall We Go This Summer and Fire on the Mountain also create the imagery deeply associated with the melancholic psychic life of Sita and the seclusion and deserted condition of Nanda Kaul. Similarly the wild and unbridled nature of Raka is mirrored in the burnt house on the top of the mountain. The titles of Anita Desai's novels are also suggestive. The cry of the peacock for lover, its mortal agony, has been identified with Maya's fate, her sure knowledge of death. The image of fire, expressive of violence, life preying upon life forms the title Fire on the Mountain. The fire destroys everything, so it is like a devouring monster 
Anita Desai effectively depicts Indian immigrants' problem of acculturation in England. She calls these immigrants as 'blackbirds' who have been fluttering their wings in an alien land of white people. She presents blackbirds as marginalized, dislocated, rejected and unwanted foreigners who have been struggling to make their existence more significant. However, the feelings of nonbelongingness, emptiness and barrenness make their lives more insecure and scratchy. The novel opens with the arrival of Dev, Adit's friend in England. Adit is an Indian immigrant, marries with Sarah, a British girl. Their inter-racial/inter-cultural marriage invites clash between two cultures.

Mala, an immigrant housewife also narrates her distressing and painful experience when a gang of English children chased her son. Her son screamed in despair: 'I'm not black! I'm not blackI'm grey! (26). The defensive mechanism of the boy evidences a sense of insecurity among Indian immigrants in England who are treated as 'outsiders' or 'others.'

\section{In Bye Bye Blackbird Anita Desai} tackles issues pertaining to racial and cultural prejudices, adjustment and acceptance, and the subjective and

objective views of a historical situation hard to shake off. Racial discrimination and cultural dominance on the basis of colour of skin and nationality are the vulnerable and sensitive problems in British society. Therefore, hostility and rejection of the host country lead immigrants toward weakening their existence in an alien land. The immigrants' desperate attempt to get back to their roots and identity is a result of their cultural rootlessness and discriminatory attitude of the host country.

Anita Desai presents the major theme of alienation to literary treatment adequately in her novels. Her main characters are caught in varied trying predicaments caused either by situation or by their own wives or parents. Hapless as they are, they fall as preys to knotty circumstances and become alienates of different kinds. Monisha feel alienation of loneliness in Voices in the City Nirode also suffers in multiple sufferings not only self imposed alienation, but also from alienation of the neurotic alienation of on artist and alienation of the competitive society.

\section{Works Cited List}




\section{ELK}

Asia Pacific Journals

[1] Desai, Anita. Cry the Peacock, New

Delhi: Orient Paperbacks, 1990

[2] Desai, Anita. Voices in the City (New

Delhi: Orient Paperbacks, 1985)

[3] Desai, Anita. Bye Bye Blackbird New

Delhi: Orient Paperbacks, 1985)

[4] Gopal, N.R. A Critical Study of the Novels of Anita Desai, New Delhi: Atlantic Publisher and Distributors, 1995.

[5] Rao, B. Ramachandra. The Novels of Mrs. Anita Desai- A study Kalyani

Publishers, 1977, Luthiana. 